Hana Bednaříková

gioconda.2005@post.cz

\title{
Zeyer znovu objevovaný. \\ Julius Zeyer, lumírovský básník v duchovním dění Evropy, edičně připravili Jiří Kudrnáč, Luisa Nováková, Zuzana Urválková, Michal Fránek, Miroslava Novotná a Tereza Riedlbauchová, HOST, Brno 2009
}

ABSTRACT. Bednaříková Hana, Julius Zeyer, lumírovský básník v duchovním dění Evropy, edičně připravili Jiří Kudrnáč, Luisa Nováková, Zuzana Urválková, Michal Fránek, Miroslava Novotná a Tereza Riedlbauchová, HOST, Brno 2009, ss. 480 (Zeyer znovu objevovaný. Julius Zeyer, lumírovský básník v duchovním dění Evropy, edičně připravili Jiří Kudrnáč, Luisa Nováková, Zuzana Urválková, Michal Fránek, Miroslava Novotná a Tereza Riedlbauchová, HOST, Brno 2009, pp. 480). „Poznańskie Studia Slawistyczne” 1. Poznań 2011. Rys Press, pp. 321-323. ISSN 2084-3011.

Sborník Julius Zeyer-lumírovský básník v duchovním dění Evropy je souhrnem statí z mezinárodní konference, kterou v roce 2007 uspořádal Ústav české literatury a knihovnictví Filozofické fakulty Masarykovy Univerzity v Brně ve spolupráci s dalšími odbornými pracovišti. Mnohostranná reflexe díla a osobnosti Julia Zeyera (1841-1901) v kontextu ustavující se moderny konce 19. století je živá a stále podnětná, lze připomenout třeba projekt Tomáše Vlčka Texty, sny, obrazy z devadesátých let nebo monografii britského bohemisty Roberta Pynsenta Julius Zeyer, 
the Path to Decadence (1973), která působila jako myšlenkově provokativní text $\mathrm{v}$ tom nejlepším smyslu slova $\mathrm{v}$ metodologicky rigidním prostředí tehdejší české literárněvědné bohemistiky.

V celkové koncepci sborníku má bezesporu rámcový význam stat' z pozůstalosti romanisty Jaroslava Fryčera Zeyerova role v české literatuře na konci 19. století. Česká dekadence, novoromantismus a modernismus - francouzský přiklad. Vedle detailní a jasnozřivé analýzy prvků vizualizace v Zeyerově př́znakově historizujícím stylu Fryčer konstatuje: „Tento autor vytváríi na jedné straně typicky českou podobu novoromantismu, blízkou secesi, na druhé straně představuje tu část v českém modernismu, kterou nazýváme francouzským př́kladem" (s. 23). Na jemný přechod estetického kánonu lumírovské generace $\mathrm{k}$ senzibilitě fin de siècle, jako na jeden z možných ,zcizujících” faktorů v dobovém chápání Zeyerova díla poukázal Viktor Viktora: „Secese (...) inklinovala $\mathrm{k}$ touze, melancholii, zasnění, tlumenému tragismu. Tyto pocity nebyly obecně charakteristické pro literaturu osmdesátých let. Začala je chápat Moderna..." (s. 60).

$\mathrm{V}$ průsečíku metodologických př́stupů v rámci historicky podmíněných poetik poukazuje například Drahomíra Vlašínová na barokní aspekty Zeyerova díla, srovnávací prístupy, které sledují Zeyerovy texty z hlediska jeho mnohdy eklektické recepce z evropských i orientálních literatur, představuje (mezi mnoha jinými) studie Mariána Gálika, pojednávající o Zeyerově vztahu k čínské literatuře, otázkami převážně dobových kritických ohlasů se zabývá Michal Fránek, další okruh textů ukazuje Zeyerovu osobnost také biograficky jako účastníka společenského života, jehož součástí byla také bohatá epistolární kultura.

Významná část publikovaných prací směřuje k alternativním pohledům na kontexty, do nichž může vstupovat literární dílo. Michal Topor ve stati Julius Zeyer, archeolog - mezi filologií a re/konstrukcí interpretuje téma Zeyerových reálných i duchovních cest z hlediska kulturní antropologie, rakouský slavista Peter Deutschmann hledá možnosti nového výkladu v rámci poststrukturalistického konceptu:

V bohemistické literatuře bylo až př́liš často poukazováno na Zeyerovu fantazii, jeho útěk od světa (...), ale je potřebný odlišný pohled, který by umožnil rozpoznat zakotvení těchto 
snů v konkrétním světě (...). V této souvislosti je třeba konstatovat, že Zeyerovy „sny”, přinejmenším pokud jde o obsah manifestovaný $\mathrm{v}$ dramatických textech rozhodně nevypovídají o socioekonomických poměrech Zeyerovy epochy (...), mnohem spíše nesou stopy politických a nacionalistických diskurzů doby (s. 209-210).

V návaznosti na komparativní výzkumy Carla Schorskeho a Moritze Csákyho situuje Kristýna Celhofferová rámec Zeyerovy estetické a psychologické typologie do kontextu tehdejší středoevropské moderny. Budeme-li sledovat tento typ výkladu dále, je jeho součástí nepochybně také Zeyerovo zakotvení v duchovním a náboženském klimatu epochy, tak např́klad o otázkách kulturních reinterpretací konce 19. století a o Zeyerově hodnotovém chápání buddhismu pojednává př́spěvek polských badatelů Joanny Królak a Piotra Ślusarczyka, Ondřej Sládek v tomto kontextu připomíná hlubinné zdroje Zeyerovy religiozity, jejíž obrysy jsou svým synkretismem součástí tehdejší evropské senzibility: „Jsou to především umělecká estetizace, hledání osobní víry a touha po náboženské zkušenosti" (s. 49). Duchovní rozměry Zeyerova díla mohou ovšem být zdrojem i dalších mezioborových přesahů. Pozoruhodným způsobem interpretuje spirituální rovinu Zeyerova díla směrem k výtvarnému umění Aleš Filip, s touto oblastí Zeyera spojoval tvưrčí, přátelský a vzájemně inspirativní vztah s Františkem Bílkem: „Koncept posvátného obrazu, vztažený zejména ke Kristovu kříži, patří k důležitým motivům pozdního díla Julia Zeyera. Jeho působení přesahuje úzce chápanou oblast literatury, nebot' je můžeme vnímat také jako Zeyerův novoromantický příspěvek k dobovým snahám o obrodu náboženské víry a křest'anského výtvarného umění” (s. 428).

Interdisciplinární hlediska se uplatňují také v muzikologických exkurzech, které na bohatém dokumentačním materiálu objasňují mnohdy složité peripetie Zeyerových postojů k možnostem hudebního ztvárnění jeho textů (Jiří Kopecký), jak to na př́kladu Janáčkovy opery Šárka dokumentuje mimo jiné studie Jiř́ho Zahrádky. Možnosti mezioborových realizací v rámci komparativní analýzy sleduje ve studii Několik literárně teoretických poznámek $k$ novele a dramatu Dům U Tonoucí hvězdy Aleš Merenus. 
Bezesporu je třeba připomenout pečlivou ediční př́pravu textu, jež je zásluhou kolektivu autorů pod vedením Jiř́ho Kudrnáče. Zeyerovský mezioborový projekt je také př́kladem toho jak nově interpretovat a kultivovat literární dědictví. Je to dobrá intelektuální investice, př̌devším do budoucna. Zeyer si to určitě zaslouží. 